\title{
A 5 - year surveillance of wound infections at a rural tertiary hospital in Nigeria
}

\author{
*Oladeinde $\mathrm{BH}^{1}$, Omoregie $\mathrm{R}^{2}$, Olley $\mathrm{M}^{3}$, Anunibe $\mathrm{JA}^{3}$, Onifade $\mathrm{AA}^{4}$
}

1. Department of Medical Microbiology, College of Health Sciences, Igbinedion University Okada, Edo State, Nigeria.

2. School of Medical Laboratory Sciences, University of Benin Teaching Hospital, P.M.B 1111, Benin City, Edo State, Nigeria.

3. Department of pathology, Igbinedion University Teaching Hospital, Okada, Edo State, Nigeria.

4. Immunology unit, College of Medicine, University of Ibadan, Nigeria.

\begin{abstract}
Background: Wound infections are associated with increased morbidity and mortality.

Objectives: To determine the prevalence, aetiology and susceptibility profile of bacterial agents of wound infection among in- and- out patients at a rural tertiary hospital in Nigeria, within a 5 year period.

Methods: Wound swabs collected from 156 out-patients and 353 in-patients were, cultured and microbial isolates identified using standard methods. Antibiotic susceptibility testing was done on bacterial isolates.

Results: The prevalence of wound infection in 2006, 2007, 2008, 2009 and 2010 was $71.4 \%, 76.2 \%, 74.5 \%, 61.5 \%$, and $67.0 \%$ respectively. The overall prevalence of wound infection was $70.1 \%$. In all the years studied, out-patients had a higher prevalence of wound infection, but this was significant in 2007, 2009, and 2010 only. Staphylococcus aureus was the most prevalent pathogen in both in- and out - patients with the exception of 2009 where both Staphylococcus aureus and Pseudomonas aeruginosa had the same prevalence $(24.4 \%)$ among in - patients. The flouroquinolones were the most potent antimicrobial agents against bacterial isolates from both in - and out -patients.

Conclusions: Staphylococcus aureus was the most predominant etiologic agent of wound infection among in and out patients. A generally higher resistance pattern was observed among nosocomial bacterial pathogens. Prudent use of antibiotics is recommended.
\end{abstract}

Keywords: prevalence, wound infection, antibiotic resistances, rural community, Nigeria African Health Sciences 2013; 13(2): 351 - 356 http://dx.doi.org/10.4314/ahs.v13i2.22

\section{Introduction}

The unbroken skin is the first line of defense and a barrier against microbial invasion. It serves as host to a variable number of transient or contaminating bacteria. Although its low surface $\mathrm{pH}$, sebaceous fluid, and fatty acids produced inhibits the colonization and growth of pathogenic organisms ${ }^{1}$, exposure of subcutaneous tissue following loss of skin integrity provides a moist, warm, and nutritious environment that is conducive for microbial colonization and proliferation ${ }^{2}$. The progression of a wound to an infected state involves a multitude of microbial and host factors such as type, site, size and depth of the wound, the extent of non-viable exogenous

\begin{tabular}{|l|}
\hline *Corresponding author: \\
Mr. Bankole .H. Oladeinde \\
Igbinedion University Okada \\
Department of Medical Microbiology \\
College of Health Sciences \\
Edo State, Nigeria \\
Email: ??? \\
\hline
\end{tabular}

African Health Sciences Vol 13 Issue 2 June 2013 contamination, the level of blood perfusion to the wound, the general health and immune status of the host, the microbial and combined level of virulence expressed by the types of micro-organisms involved $^{2}$.

Nosocomial wound infections are a serious health concern. Infection of wound following surgery has been common in spite of recent advances made in asepsis. It is an important cause of illness, resulting in prolonged hospital stay, increased trauma care, and treatment cost. It also causes a significant strain on the surgeon and nursing staff $^{3}$, making wound management practices much more demanding. Repeat admissions following discharge have been noted to be more frequent among patients who had post operative wound infection than those without one ${ }^{3}$. Nosocomial wound infections have also been reported to be frequent in non-surgical ward of most hospitals.

The etiology of wound infection differs from country to country and from hospital to hospital even within the same region ${ }^{5}$. Control of 
wound infections has been very challenging due to widespread bacterial resistance to antibiotics and due to an increasing incidence of infection caused by methicillin - resistant Staphylococus aureus (MRSA) and polymicrobic flora ${ }^{6}$. Studies have shown that most hospitals in developing countries especially Africa, have rudimentary and highly compromised infection control programmes due to lack of awareness of the problem, lack of personnel, poor water supply, erratic electricity supply, poor laboratory back up and funding ${ }^{7}$. These factors are rife in most rural health care centres in Nigeria, and underscore the need for this study. Accurate information of the incidence and etiology of infections acquired within a hospital is essential for articulation of effective preventive measures $^{8}$. Against this background, this study was aimed at determining the prevalence of wound infection and susceptibility profile of associated aerobic bacteria from patients at a rural tertiary health care facility in Edo State. Nigeria.

\section{Methods}

\section{Study Area}

Okada, a rural community is the headquarter of Ovia Northeast local government area of Edo State, Nigeria. The local government has an estimated population of 155344 persons ${ }^{9}$. Majority of the residents of Okada are farmers with few civil servants, lecturers, and students making less than 5\% of the community. Igbinedion University Teaching Hospital is the only tertiary health care provider in Okada. Some people from neighboring rural communities (villages) also attend the Hospital.

\section{Study population}

A total of 509 (190 females and 319 males) with overt signs and symptoms of wound infection in the out - patient and in - patient departments of Igbinedion University Teaching Hospital were recruited for this study. The age range of the study population was 4 years - 73 years. Verbal informed consent was obtained from all participating subjects or their parents/guardian in case of children prior to specimen collection. The study was approved by the Ethical Committee of the Igbinedion University Teaching Hospital, Okada, Nigeria.

\section{Collection and processing of specimen}

A pair of wound swab was collected from each patient and transported to the laboratory for analysis within one hour. One of the wound swabs was used to make film and stained by gram's stain. The second swab was cultured onto blood, MacConkey and Sabouraund agar, and incubated for 24 to 48 hours at $37^{\circ} \mathrm{C}$. Candidiasis was diagnosed by the presence of yeast-like cells as well as identification of isolates from culture. Bacterial isolates were identified using standard laboratory techniques ${ }^{10}$. All yeast isolates were inoculated on CHROMAgar Candida ${ }^{\mathrm{TM}}$ and incubated for 48 hours at $37^{\circ} \mathrm{C}$. The colour produced by each colony was used to identify the yeast. Antibiotic susceptibility test for bacterial isolates was performed using the BSAC method ${ }^{11}$.

\section{Statistical analysis}

The data obtained were analyzed using Chi-square or Fischer's exact test as appropriate and odd ratio analysis using the statistical software INSTAT®.

\section{Results}

A statistically significant difference was observed between the prevalence of wound infections among in-patients (64.6\%). and out-patients (82.7\%) ( $\mathrm{p}<$ $0.0001)$. The prevalence of wound infection among out-patients from 2006 to 2010 did not differ significantly $(\mathrm{p}>0.05)$. A similar picture was observed among in-patients. However, out - patients had significantly higher prevalence than in-patients in the year 2007, 2009 and 2010 as indicated in table 1.

Age and gender did not affect the prevalence of wound infection among in- and outpatients as shown in table 2.

Staphylococcus aureus $(40.3 \%)$ was the most predominant isolate followed by Pseudomonas aeruginosa (23.9\%), while Citrobacter sp was the least $(\mathrm{H}=0.5 \%)$. Candida albicans was the only fungi isolated with a prevalence of $\mathrm{H}=1.0 \%$. In all the years - from 2006 to 2010, Staphylococcus aureus was the most prevalent pathogen in both in- and outpatients with the exception of 2009 where both Staphylococus aureus and Psendomonas aeruginosa had the same prevalence among in - patients $(24.4 \%)$ as shown in table 3 .

The flouroquinolones were the most active antibacterial agents against bacterial isolates from in and out patients studied. A generally higher resistance pattern was observed among nosocomial bacterial pathogens as indicated in tables 4 and 5 . 
Table 1: Yearly prevalence of wound infection

\begin{tabular}{|c|c|c|c|c|c|c|c|}
\hline \multirow[t]{2}{*}{ Year } & \multicolumn{2}{|c|}{ Out - patients } & \multirow{2}{*}{$\begin{array}{l}\text { In - } \\
\text { patients } \\
\mathbf{N}\end{array}$} & \multirow[b]{2}{*}{$\begin{array}{l}\text { Number } \\
\text { infected } \\
(\%)\end{array}$} & \multirow{2}{*}{ OR } & \multirow{2}{*}{$95 \% \mathrm{CI}$} & \multirow{2}{*}{ P value } \\
\hline & $\mathbf{N}$ & $\begin{array}{l}\text { Number } \\
\text { infected } \\
(\%)\end{array}$ & & & & & \\
\hline 2006 & 20 & $17(85.0)$ & 64 & $43(67.2)$ & 2.767 & $0.7290,0.506$ & 0.1614 \\
\hline 2007 & 37 & 33 (89.1) & 85 & $60(70.5)$ & 3.438 & $1.102,10.727$ & 0.0361 \\
\hline 2008 & 31 & $25(80.6)$ & 67 & 48 (71.6) & 1.649 & $0.5843,4.655$ & 0.4566 \\
\hline 2009 & 46 & $35(76.1)$ & 71 & $37(52.1)$ & 2.924 & $1.285,6.654$ & 0.0115 \\
\hline 2010 & 22 & $19(86.4)$ & 66 & $40(60.1)$ & 4.117 & $1.106,15.322$ & 0.0333 \\
\hline Total & 156 & $129(82.7)$ & 353 & $228(64.6)$ & 2.619 & $1.639,4.186$ & $<0.0001$ \\
\hline $\begin{array}{l}\text { Mixed } \\
\text { infection }\end{array}$ & 2006-2010 & $12(9.3)$ & $28(12.3)$ & & 0.7326 & $0.3588,1.496$ & 0.4855 \\
\hline
\end{tabular}

$\mathrm{N}$ - number tested; OR - odd ratio; CI - confidence interval; pvalue (Out - Patients) $=0.427$; $\mathrm{p}$ value (InPatients) $=0.104$

Table 2: Effect of gender and age on prevalence of wound infection

\begin{tabular}{llllll}
\hline Characteristics & \multicolumn{2}{l}{ Out - patients } & \multicolumn{2}{l}{ In - patients } \\
& $\mathbf{N}$ & $\mathbf{N ~ P o s ~ ( \% )}$ & $\mathbf{N}$ & $\mathbf{N ~ P o s ~ ( \% )}$ & P value \\
\hline Male & 52 & $41(78.8)$ & 138 & $83(60.1)$ & 0.017 \\
Female & 104 & $88(84.6)$ & 215 & $145(67.4)$ & 0.001 \\
Age (years) & & & & & \\
$5-14$ & 12 & $12(100)$ & 31 & $24(77.4)$ & 0.163 \\
$15-24$ & 25 & $19(76.0)$ & 56 & $35(62.5)$ & 0.310 \\
$25-35$ & 20 & $15(75.0)$ & 49 & $27(55.1)$ & 0.176 \\
$35-44$ & 33 & $23(69.7)$ & 61 & $30(49.2)$ & 0.081 \\
$45-54$ & 21 & $18(85.7)$ & 53 & $40(75.5)$ & 0.532 \\
$55-64$ & 17 & $15(88.2)$ & 79 & $51(64.6)$ & 0.082 \\
$\geq 65$ & 28 & $27(96.4)$ & 24 & $21(87.5)$ & 0.324 \\
\hline
\end{tabular}

$\mathrm{N}$-number tested; Out-patients (Male v Female): $\mathrm{p}=0.378$; In -patient: (Male v Female): $\mathrm{p}=0.199$; Out patients (Age): $\mathrm{p}=0.156$; In-patients (Age): $\mathrm{p}=0.28$

Table 3: Distribution of micro-organism from infected wound

\begin{tabular}{|c|c|c|c|c|c|c|c|c|c|c|c|}
\hline \multirow[t]{3}{*}{ Organism } & \multirow{3}{*}{$\begin{array}{l}\text { Number } \\
(\%)\end{array}$} & \multicolumn{2}{|c|}{2006} & \multicolumn{2}{|c|}{2007} & \multicolumn{2}{|c|}{2008} & \multicolumn{2}{|c|}{2009} & \multicolumn{2}{|c|}{2010} \\
\hline & & Out & In & Out & In & Out & In & Out & In & Out & In \\
\hline & & $\begin{array}{l}\text { patients } \\
(\%)\end{array}$ & $\begin{array}{l}\text { patients } \\
(\%)\end{array}$ & $\begin{array}{l}\text { patients } \\
(\%)\end{array}$ & $\begin{array}{l}\text { patients } \\
(\%)\end{array}$ & $\begin{array}{l}\text { patients } \\
(\%)\end{array}$ & $\begin{array}{l}\text { patients } \\
(\%)\end{array}$ & $\begin{array}{l}\text { patients } \\
(\%)\end{array}$ & $\begin{array}{l}\text { patients } \\
(\%)\end{array}$ & $\begin{array}{l}\text { patients } \\
(\%)\end{array}$ & $\begin{array}{l}\text { patients } \\
(\%)\end{array}$ \\
\hline Eschericbia coli & $54(13.5)$ & $3(15.0)$ & $6(12.0)$ & $9(26.5)$ & $9(14.1)$ & $1(3.5)$ & $9(16.7)$ & $1(2.4)$ & $6(13.3)$ & $1(4.8)$ & $9(20.5)$ \\
\hline Klebsiella spp & $35(8.7)$ & $1(5.0)$ & $1(2.0)$ & $4(11.7)$ & $7(10.9)$ & $1(3.5)$ & $4(7.4)$ & $3(7.3)$ & $9(20.0)$ & $2(9.6)$ & $3(6.8)$ \\
\hline Proteus spp & $36(8.9)$ & $0(0.0)$ & $1(2.0)$ & $3(8.8)$ & $5(7.8)$ & $4(14.2)$ & $6(11.1)$ & $0(0.0)$ & $5(11.1)$ & $3(14.3)$ & $9(20.5)$ \\
\hline $\begin{array}{l}\text { Pseudomonas } \\
\text { aeruginosa }\end{array}$ & $96(23.9)$ & $5(25.0)$ & $12(24.0)$ & $6(17.6)$ & $16(25.0)$ & $7(25.0)$ & $15(27.8)$ & $11(26.8)$ & $11(24.4)$ & $4(19.0)$ & $9(20.5)$ \\
\hline Citrobacter spp & $2(0.5)$ & $0(0.0)$ & $0(0.0)$ & $0(0.0)$ & $0(0.0)$ & $0(0.0)$ & $0(0.0)$ & $0(0.0)$ & $0(0.0)$ & $0(0.0)$ & $0(0.0)$ \\
\hline $\begin{array}{l}\text { Staphylococcus } \\
\text { aureus }\end{array}$ & $162(40.3)$ & $10(50.0)$ & $29(58.0)$ & $10(29.4)$ & $24(37.5)$ & $14(50.0)$ & $20(37.0)$ & $22(53.6)$ & $11(24.4)$ & $8(38.1)$ & $14(31.8)$ \\
\hline Streptococcus & $5(1.2)$ & $0(0.0)$ & $0(0.0)$ & $0(0.0)$ & $2(3.1)$ & $1(3.5)$ & $0(0.0)$ & $0(0.0)$ & $2(4.5)$ & $0(0.0)$ & $0(0.0)$ \\
\hline $\begin{array}{l}\text { Enterococcus } \\
\text { feacalis }\end{array}$ & $7(1.7)$ & $0(0.0)$ & $1(2.0)$ & $1(2.9)$ & $0(0.0)$ & $0(0.0)$ & $0(0.0)$ & $1(2.4)$ & $1(2.2)$ & $3(14.3)$ & $0(0.0)$ \\
\hline $\begin{array}{l}\text { Candida } \\
\text { albicans }\end{array}$ & $4(4)$ & $1(5.0)$ & $0(0.0)$ & $1(2.9)$ & $1(1.6)$ & $0(0.0)$ & $0(0.0)$ & $1(2.4)$ & $0(0.0)$ & $0(0.0)$ & $0(0.0)$ \\
\hline Total & & 20 & 50 & 34 & 64 & 28 & 54 & 41 & 45 & 21 & 44 \\
\hline
\end{tabular}


Table 4: Susceptibility profile of bacterial isolates from in patients

\begin{tabular}{|c|c|c|c|c|c|c|c|c|c|c|}
\hline \multirow[t]{2}{*}{ Bacterial agents (n) } & CIP & OFX & CAZ & CRO & GEN & $\overline{\mathrm{AU}}$ & SXT & $\mathrm{TE}$ & $\overline{\mathrm{AM}}$ & CHL \\
\hline & $(10)(\%)$ & $(10)(\%)$ & $(30)(\%)$ & $(25)(\%)$ & $(10)(\%)$ & $(30)(\%)$ & $(30)(\%)$ & $(10)(\%)$ & $(30)(\%)$ & $(30)(\%)$ \\
\hline Escherichia coli (39) & $30(76.9)$ & $32(82.5)$ & $28(71.8)$ & $27(69.2)$ & $19(48.7)$ & $21(53.8)$ & $0(0.0)$ & $0(0.0)$ & $0(0.0)$ & $0(0.0)$ \\
\hline Klebsiella spp (24) & $19(79.1)$ & $19(79.1)$ & $17(70.8)$ & $14(58.3)$ & 10(41.6) & $14(58.3)$ & $0(0.0)$ & $0(0.0)$ & $0(0.0)$ & $0(0.0)$ \\
\hline Proteus spp (26) & $20(76.9)$ & $21(80.7)$ & $18(69.2)$ & $18(69.2)$ & $7(26.9)$ & $10(38.5)$ & $0(0.0)$ & $0(0.0)$ & $0(0.0)$ & $0(0.0)$ \\
\hline Psendomonas aeruginosa (63) & $51(80.9)$ & $53(84.1)$ & $50(79.3)$ & $52(82.5)$ & $29(46.0)$ & $36(57.1)$ & $0(0.0)$ & $0(0.0)$ & $0(0.0)$ & $0(0.0)$ \\
\hline Staphylococcus aureus (98) & $72(73.5)$ & $80(81.6)$ & $75(76.5)$ & $70(71.4)$ & $48(48.8)$ & $57(58.2)$ & $0(0.0)$ & $0(0.0)$ & $0(0.0)$ & $0(0.0)$ \\
\hline Streptococcus pyogenes (4) & $4(100.0)$ & $4(100.0)$ & $4(100.0)$ & $2(50.0)$ & $2(50.0)$ & $3(75.0)$ & $0(0.0)$ & $0(0.0)$ & $0(0.0)$ & $0(0.0)$ \\
\hline Enterococcus feacalis (2) & $2(100.0)$ & $2(100.0)$ & $2(100.0)$ & $1(50.0)$ & $1(50.0)$ & $2(100.0)$ & $0(0.0)$ & $0(0.0)$ & $0(0.0)$ & $0(0.0)$ \\
\hline
\end{tabular}

CIP - Ciprofloxacin; OFX - Ofloxacin; CAZ- Ceftriaxone; CRO- Ceftazidime; GEN- Gentamicin; AUAmoxicillin- Cluvalanate; SXT-Sulfamethoxazole; TE- Tetracycline; AM-Ampxycillin; CHL- Chloramphenicol

Table 5: Susceptibility profile of bacterial isolates from out patients

\begin{tabular}{|c|c|c|c|c|c|c|c|c|c|c|}
\hline \multirow[t]{2}{*}{ Bacterial agents (n) } & $\mathrm{CIP}$ & OFX & CAZ & CRO & GEN & $\mathrm{AU}$ & SXT & $\mathrm{TE}$ & $\mathrm{AM}$ & CHL \\
\hline & $(10)(\%)$ & $(10)(\%)$ & $(30)(\%)$ & $(25)(\%)$ & $(10)(\%)$ & $(30)(\%)$ & $(30)(\%)$ & $(10)(\%)$ & $(30)(\%)$ & $(30)(\%)$ \\
\hline Eschericbia coli (15) & $14(93.3)$ & $15(100.0)$ & $13(86.0)$ & $13(86.0)$ & $10(66.6)$ & $11(73.3)$ & $0(0.0)$ & $0(0.0)$ & $0(0.0)$ & $0(0.0)$ \\
\hline Kebsiella spp (11) & $9(81.8)$ & $9(81.8)$ & $9(81.8)$ & $7(63.6)$ & $5(45.5)$ & $7(63.6)$ & $0(0.0)$ & $0(0.0)$ & $0(0.0)$ & $0(0.0)$ \\
\hline Proteusspp (10) & $9(90.0)$ & $8(80.0)$ & $8(80.0)$ & $7(70.0)$ & $4(40.0)$ & $6(60.0)$ & $0(0.0)$ & $0(0.0)$ & $0(0.0)$ & $0(0.0)$ \\
\hline Psendomonas aeruginosa (33) & $26(78.8)$ & $28(84.8)$ & $27(81.8)$ & $25(75.7)$ & $20(60.6)$ & $22(66.6)$ & $0(0.0)$ & $0(0.0)$ & $0(0.0)$ & $0(0.0)$ \\
\hline Citrobacter spp (2) & $2(100.0)$ & $2(100.0)$ & $2(100.0)$ & $2(100.0)$ & $2(100.0)$ & $2(100.0)$ & $0(0.0)$ & $0(0.0)$ & $0(0.0)$ & $0(0.0)$ \\
\hline Stapbylococcus aureus (64) & $55(65.9)$ & $60(93.7)$ & $58(90.6)$ & $56(87.5)$ & $41(64.1)$ & $53(82.8)$ & $0(0.0)$ & $0(0.0)$ & $0(0.0)$ & $0(0.0)$ \\
\hline Streptococcuspyogenes (1) & $1(100.0)$ & $1(100.0)$ & $1(100.0)$ & $1(100.0)$ & $1(100.0)$ & $1(100.0)$ & $0(0.0)$ & $0(0.0)$ & $0(0.0)$ & $0(0.0)$ \\
\hline Enterococcus feacalis (5) & $4(80.0)$ & $5(100.0)$ & $4(80.0)$ & $4(80.0)$ & $2(40.0)$ & $4(80.0)$ & $0(0.0)$ & $0(0.0)$ & $0(0.0)$ & $0(0.0)$ \\
\hline
\end{tabular}

CIP - Ciprofloxacin; OFX - Ofloxacin; CAZ- Ceftriaxone; CRO- Ceftazidime; GEN- Gentamicin; AUAmoxicillin- Cluvalanate; SXT- Sulfamethoxazole; TE- Tetracycline; AM-Ampxycillin; CHL- Chloramphenicol

\section{Discussion}

Epidemiological surveillance of infection is indispensable for effective management of diseases, and the creation and implementation of control measures. This is particularly important in resources poor settings in Africa, were data on disease prevalence is sparsely documented, and prevailing factors such as poor access to running water, poor hygiene, poverty and illiteracy often serves as catalyst for spread of diseases. Although a number of studies have been conducted on wound infections in some hospital and clinics in Nigeria, to the best of our knowledge, none has focused on its prevalence and etiology among in and out patients in a rural health care facility.

The overall prevalence of wound infection in this study was $70.1 \%$. This agrees with a previous report $^{12}$, but is at variance with others ${ }^{4,13,14}$. The etiology of wound infection differs from country to country and from hospital to hospital even within the same region ${ }^{5}$. 
This coupled with the differences in nature and site of wound infection in study centers may account for the observed variation. In all the years studied, no statistically significant difference was recorded in prevalence of wound infection among in- and outpatients. Generally, a significantly higher prevalence of wound infection was observed among outpatients $(82.7 \%)$ than in - patients $(64.6 \%)$ during the years of this study. Okada and other neighboring communities are strictly rural settings with inhabitants being largely farmers. High rate of occupational related injuries, poor hygiene and accessibility to health care facility may be responsible for the observed trend. Age and gender did not significantly affect the prevalence of wound infection in this study. These have been previously confirmed in two separate Nigerian studies ${ }^{14,15}$. In all the years studied, Staphylococcus aureus was the most prevalent in both in- and out-patients with the exception of 2009 where both Staphylococus aureus and Pseudomonas. aeruginosa had the same prevalence among in - patients (24.4\%). The leading role of Staphylococus aureus and Pseudomonas aeruginosa in wound infection has been severally documented ${ }^{14,16}$. Candida albicans was the only fungal specie isolated from this study.

Generally among bacterial isolates from in and out patients, the flouroquinolones (Ciprofloxacin and Ofloxacin) were the most potent antimicrobial agents observed. Irrespective of source, Sulfamethoxazole -Trimethoprim, Tetracycline, Amoxicillin and Chloramphenicol were found to have no activity on bacterial isolates. Prescription of antibiotics without laboratory guidance as well as over the counter sales of antibiotics without prescription have been noted to be rife in Nigeria ${ }^{17}$. These antibiotics with no activity against bacterial isolates are cheap to procure in Nigeria. This coupled with the ease of accessibility encourages their misuse and overuse, leading to the development of bacterial resistance over time. Antimicrobial susceptibility testing of bacterial isolates in five year period under study revealed that nosocomial pathogens were generally more resistant to antibiotics as compared to those from out - patients. Selective pressure due to repeated use of disinfectants in hospital settings may account for this observation.

\section{Conclusion}

An overall prevalence of $70.1 \%$ of wound infection was observed in this study, with prevalence being significantly higher generally among out-patients. With the exception of 2009 , where the prevalence of
Staphylococus aureus and Pseudomonas aeruginosa were the same (24.4\%), among in - patients, Staphylococcus aureus was the most predominant etiologic agent of wound infection observed among in- and out- patients. The flouroquinolones were the most active antimicrobial agents observed among bacterial isolates from in and out patients studied. However a generally higher antimicrobial resistance pattern was observed among nosocomial pathogens. Prudent use of antibiotics is advocated.

\section{Acknowledgement}

The authors acknowledge with thanks the ethical committee of the Igbinedion University Teaching Hospital Okada, for their permission to conduct this study.

\section{References}

1. Stephan J, Landis MD. Chronic wound infection and antimicrobial use advances in skin and wound care. J Prev Healing. 2008; 21(11):531540.

2. Bowler PG, Duerden BI, Armstrong DG. Wound microbiology and associated approaches to wound management. Clin Microbiol Rev. 2001; 14(2):244-269.

3. Mofikoya BO, Neimogha M, Ogunsola FF, Atoyebi OA. Bacterial agents of abdominal surgical site infection in Lagos, Nigeria. Eur J Scient Res. 2009; 38(3):509-513.

4. Taiwo SS, Okesina AB, Onile B.A. Invitro antimicrobial pattern of bacterial isolates from wound infection in University of Illorin Teaching Hospital. Afr J Clin Exp Microbiol.2002; 3(1):610.

5. Biadglegna F, Abera B, Alem A, Anagaw B. Bacterial isolates from wound infection and their antimicrobial susceptibility pattern in Felege Hiwot referral Hospital North West Ethiopia. Ethiop J Health Sci. 2009; 19 (3):173-179.

6. Akinjogunla OA, Adegoke AA, Mboto CL, Chukwudebelu IC, Udakang IP. Bacteriology of automobile accident wound infection. Int $J$ Med Med Sci. 2009; 1(2):23-25.

7. Samuel SO, Kayode OO, Musa OJ, et al. Nosocomial infections and the challenges of control in developing countries. Afr J Clin Exp Microbiol. 2010; 11(2):102-110.

8. Sanjay KR, Nagandar-Prasad MN, Vijaykumar GJ. A study on isolation and detection of drug resistance gram negative bacilli with special 
importance to post operative wound infection. J Microbiol Antimicrob. 2010; 2(6):68-75.

9. National Population Commission. Population and Housing Census of the Federal Republic of Nigeria. 2006

10. Barrow GI, Feltman RKA. Cowan and Steel's manual for the identification of medical bacteria ( $3^{\text {rd }}$ edition) Cambridge University Press 2003.

11. British Society for Antimicrobial Chemotherapy. BSAC methods for Antimicrobial susceptibility testing. Version 8, 2009.

12. Azene K, Beyeme B.A. Bacteriology and antibiogram of pathogens from wound infections at Dessie Laboratory, North East Ethiopia. Tanzania J Health Res. 2011; 13(4):110.

13. Isibor JO, Oseni A, Eyaufe A, Osagie R, Turay A. Incidence of aerobic bacteria and Candida albicans in post-operative wound infections. Afr J Microbiol Res. 2008; 2:288-291.
14. Egbe CA, Omoregie R, Igbarumeh IO, Onemu S. Microbiology of wound infections and associated risk factors among patients of a Tertiary Hospital in Benin City, Nigeria. $J$ Res Health Sci. 2011; 11(2):109-113.

15. Ezebialu CU, Chukwura EI, Ezebialu I U. Bacterial pathogens associated with wound infection at National Orthopaedic Hospital Enugu. Nigerian J Microbiol. 2010; 24(1):19871992.

16. Akinjogunla OA, Adegoke AA, Mboto CL, Chukwudebelu IC, Udakang IP. Bacteriology of automobile accident wound infection. Int $\mathrm{J}$ Med Med Sci. 2009; 1(2):23-27.

17. Omoregie R, Christopher AE, Igbarumah IO, Ogefere H, Okorie E. Prevalence and etiologic agents of female reproductive tract infection among in-patients and out-patients of a tertiary hospital in Benin City. Nigeria. North Am J Med Sci.2010; 2(10):473-477. 